\title{
Social Work, Politics, and Social Policy Education: Applying a Multidimensional Framework of Power
}

\author{
Amy Krings \\ Loyola University Chicago, akrings@luc.edu \\ Vincent Fusaro \\ Boston College \\ Kerri L. Nicoll \\ Massachusetts College of Liberal Arts \\ $\mathrm{Na}$ Youn Lee \\ University of Mississippi
}

Follow this and additional works at: https://ecommons.luc.edu/socialwork_facpubs

Part of the Social Work Commons

\section{Author Manuscript}

This is a pre-publication author manuscript of the final, published article.

\section{Recommended Citation}

Krings, A., Fusaro, V., Nicoll, K. L., \& Lee, N. Y. (2019). Social work, politics, and social policy education: Applying a multidimensional framework of power. Journal of Social Work Education, 55(2), 224-237.

This Article is brought to you for free and open access by the Faculty Publications and Other Works by Department at Loyola eCommons. It has been accepted for inclusion in Social Work: School of Social Work Faculty Publications and Other Works by an authorized administrator of Loyola eCommons. For more information, please contact ecommons@luc.edu.

\section{cc (i) $\ominus$}

This work is licensed under a Creative Commons Attribution-Noncommercial-No Derivative Works 3.0 License.

(c) Taylor \& Francis, 2019. 


\title{
Social Work, Politics, and Social Policy Education: Applying a Multidimensional Framework of Power
}

\author{
Amy Krings, Vincent Fusaro, Kerri Leyda Nicoll \& Na Youn Lee
}

\section{Notes on contributors}

Amy Krings is an Assistant Professor at Loyola University Chicago, Vincent Fusaro is an Assistant Professor at Boston College, Kerri Leyda Nicoll is an Assistant Professor at Massachusetts College of Liberal Arts, and $\mathrm{Na}$ Youn Lee is an Assistant Professor at University of Mississippi.

\section{Corresponding Author}

Amy Krings, akrings@luc.edu, Loyola University Chicago, School of Social Work, 1 East Pearson Street, 530 Maguire Hall, Chicago, IL 60611

\section{Copyright Agreement}

The Version of Record of this manuscript has been published and is available in Journal of Social Work Education, 2019, DOI: 10.1080/10437797.2018.1544519

\section{Complete Citation}

Amy Krings, Vincent Fusaro, Kerri Leyda Nicoll \& Na Youn Lee (2019): Social Work, Politics, and Social Policy Education: Applying a Multidimensional Framework of Power, Journal of Social Work Education, DOI: 10.1080/10437797.2018.1544519

\footnotetext{
ABSTRACT

The call to promote social justice sets the social work profession in a political context. In an effort to enhance social workers' preparedness to engage in political advocacy, this article calls on educators to integrate a broad theoretical understanding of power into social policy curricula. We suggest the use of a multidimensional conceptualization of power that emphasizes mechanisms of decision making, agenda control, and attitude formation. We then apply these mechanisms to demonstrate how two prominent features of contemporary politics - party polarization and racially biased attitudes-affect the ability of social workers to influence policy. Finally, we suggest content that social work educators can integrate to prepare future social workers to engage in strategic and effective social justice advocacy.
} 


\title{
Social Work, Politics, and Social Policy Education: Applying a Multidimensional Framework of Power
}

\author{
Amy Krings, Vincent Fusaro, Kerri Leyda Nicoll \& Na Youn Lee
}

As part of their broader mandate, codified in the National Association of Social Workers (2017) Code of Ethics, social workers are called to advance social and economic justice by participating in political action with, or on behalf of, disadvantaged groups. The goals of such action are broad democratic participation, a fair distribution of power and resources, and an equitable distribution of opportunities (Reisch \& Garvin, 2016). To achieve these goals, social workers must go beyond an analysis of how existing policies reinforce or reduce social problems to recognize and strategically engage with the power embedded in political processes themselves. This power not only influences how problems are addressed or ignored but also how they are constructed and understood. Thus, to be effective practitioners and change agents, it is necessary for social workers to "see power as central to understanding and addressing social problems and human needs” (Fisher, 1995, p. 196).

At its inception, the social work profession emerged as a leader in shaping policies and programs that improved the health and well-being of disadvantaged people and families. Social workers played key roles in policy areas such as aid to families, Social Security, the juvenile court system, minimum wage, and unemployment insurance (Axinn \& Stern, 2012). Over time, external pressures, including austerity-driven policies that emphasize market-based approaches to social service delivery and the reduction of the social safety net, have limited the range of microlevel interventions and marginalized mezzo- and macro level community and policy practice (Abramovitz \& Sherraden, 2016; Reisch, 2000). Consequently, many social work educators have expressed concern that the profession has become increasingly depoliticized and decontextualized by focusing disproportionately on individual interventions at the expense of systematic interventions that could help individuals and communities thrive (Abramovitz, 1998; Abramovitz \& Sherraden, 2016; Specht \& Courtney, 1995).

Given this context, we encourage social work practitioners and educators to vigorously renew their commitment to, and engagement in, political processes to advance programs and policies that support the health and well-being of marginalized groups. In an effort to enhance social workers' confidence and ability to engage in political advocacy, we recommend that social work educators integrate a broad theoretical understanding of power in social policy courses, coupled with comprehensive knowledge about the mechanisms used to channel power into political processes. Toward this end, we introduce a multidimensional conceptualization of power (Lukes, 2005); demonstrate its relevance to two prominent features of contemporary politics — political polarization and racially biased political attitudes - and offer content that social work educators 
can integrate into their classes to prepare future social workers to engage in strategic and effective social justice advocacy.

\section{A multidimensional framework of political power}

To broaden the depth and nuance of social workers' understanding of political power, we suggest the inclusion of what Lukes (2005) conceptualized as three dimensions of power: decision-making power, agenda-setting power, and ideological power. The three dimensions are not mutually exclusive and can emerge in a cumulative, compounding fashion (Culley \& Hughey, 2008). In the following sections, we summarize each dimension and introduce its underlying assumptions relating to political participation, political equality, and policy making. It should be noted that although we agree with social work scholars who argue that power is a pervasive aspect of social life and central to all social work practice (Fisher, 1995; Rees, 1991), for the purposes of this article, we focus on the ways power is channeled within the United States federal system.

\section{The first dimension: Decision-making power}

The first dimension of power, often referred to as decision-making power, conceives of power as intentional, active, and observable by examining who decides and who prevails in political conflicts (Dahl, 1958; Gaventa, 1980). Lukes (2005) conceptualized this dimension as consistent with the theory of pluralism because it assumes that (a) when a group of people have a concern about a social problem, they will act on it, and (b) the political system is open and accessible to all. Consequently, pluralists suggest that when a grievance emerges, those who are affected by it will be willing and able to become involved in political decision making (Dahl, 1961). Furthermore, all citizens possess some form of political resources (i.e., votes, money, property, or authority) they can use to trade, reward, or punish their political allies and opponents (Polsby, 1960). Because the political system is conceived as relatively open and accessible to all, pluralists suggest there is no ruling elite in American politics because no single group commands sufficient resources to control all others, and every group commands some resources. Nonparticipation can be viewed as a reflection of general consensus and approval.

Lukes (2005) argues that under some conditions citizens can successfully express their preferences to elected officials through activities like voting, providing testimony, or signing a petition. However, he emphasizes that influence through decision-making power is the most limited of the three dimensions, and its assumptions and ability to accurately predict political outcomes have been challenged. Nonetheless, many of the tactics taught in social policy classes or used by politically active social workers remain at the level of decision-making power.

Drawing on random samples of social workers, Rome and Hoechstetter (2010) and Ritter (2007) found that less than half of practitioners report that they are strongly engaged in political 
activities. Of those who are engaged, common political activities included voting, writing letters, following the news, discussing politics, and knowing who their political representatives are (Mary, 2001; Pritzker \& Burwell, 2016). A small number of social workers run for political office (Lane \& Humphreys, 2011). More direct policy-making activities, such as attending hearings, providing testimony to policy makers, canvassing door to door, making monetary donations to candidates, and engaging in activist behaviors such as demonstrations, were not common (Mary, 2001; Ritter, 2007; Rome \& Hoechstetter, 2010). Overall, the portrait of social workers as political actors suggests that they are engaged with electoral activities such as voting but are less engaged with activities that happen earlier in the political process, such as setting the agenda or influencing the framing of political issues.

Social work education also conceptualizes political processes narrowly. The curricula of policy courses in accredited social work education programs include a history of social welfare policies, a description and critique of the contemporary welfare state, and general information on the structure and functioning of government (Council on Social Work Education, 2015). However, the bulk of this information is about the social welfare system as it is, as opposed to analytical or practical skills that support change efforts. Additionally, basic civic literacy among social workers, such as knowledge of how political institutions function or of important historical developments in the American political system, remains a concern. Social work students in two studies scored fairly low on standard tests of civic literacy, although they did score somewhat better than the general public (Hylton, 2015; McCabe, Hylton, Kooreman, Sarmiento, \& Day, 2017). Nearly half of Ritter's (2007) and more than a third of Rome and Hoechstetter's (2010) respondents reported they did not feel prepared to participate in politics. Activities such as advocacy days (Beimers, 2016; DeRigne, Rosenwald, \& Naranjo, 2014; Kilbane, Pryce, \& Hong, 2013) and voter registration (Pritzker \& Burwell, 2016) are used to expose students to advocacy activities. However, activities that shape political agendas, such as agenda setting and issue framing, are underemphasized in social work education. Thus, if social workers wish to take seriously their mission to advance social and economic justice, the social work curriculum must broaden its conceptualizations of political power and civic engagement.

\section{The second dimension: Agenda-setting power}

The second dimension of power includes the ability to influence the policy-making agenda. This dimension includes a gatekeeping function that shapes the content and timing of what is being debated by prioritizing, delaying, or blocking some issues from contention (Bachrach \& Baratz, 1962). Although the first dimension of power emphasizes active decision-making power, the second dimension suggests that power can manifest itself actively or passively. Gatekeeping takes an active form when political leaders consciously decide to advance or prioritize discussion on a particular set of issues. However, leaders can also make what theorists Bachrach and Baratz (1962, p. 949) call "non-decisions" by choosing to delay or suppress a discussion or a vote on a 
subject. In this way, issues are effectively blocked before entering the policy-making process. The second dimension of power also suggests that "the rules of the game" (e.g., institutional procedures) can systematically benefit one group over another by determining who is eligible to participate in political processes and on what terms (Bachrach \& Baratz, 1962, p. 950). These rules can influence who participates in political processes by mobilizing some groups while demobilizing others (Schattschneider, 1960).

Consequently, if political participants (such as social workers) exclusively attend to issues that are already on policy-making agendas, they will be excluded from opportunities to shape political agendas or to influence the processes used to select people to make political decisions. This dynamic is particularly important for social workers because many of the issues that are blocked through agenda control are considered a challenge to the status quo and are potentially the very issues that could advance social and economic justice. This suggests that social work practitioners and educators should engage with policy makers through community organizations, interest groups, and social movements to influence political agenda-setting and rules that support fair decision-making processes.

\section{The third dimension: Ideological power}

The third dimension of power is the most comprehensive, yet least visible, of the three. It suggests that power can be exercised by influencing what is thought to be possible, imperative, or desirable (Gaventa, 1980; Lukes, 2005). Ideological power works by influencing one's

political attitudes, preferences, and imagination; the result of this kind of power is that some issues are never even conceived of as social problems worthy of political action. As such, they do not need to be voted on (as in the first dimension) or blocked from the policy-making agenda (as in the second dimension).

Political attitudes and preferences are shaped through many mechanisms (Tilly, 1991). In some cases, political and economic elites might control the flow of information through mass media or education. As a result, people who are oppressed may come to internalize the values of their oppressors (Freire, 1970), or they might not interpret their personal problems as resulting from political issues (Mills, 1959). In other instances, people might be unable to imagine alternative political, economic, or social systems. Finally, there may be instances in which the mere reputation of power among a particular circle of elites discourages others from participating politically. For example, Crenson (1971) found that low-income residents in Gary, Indiana, were not willing to organize to promote pollution-control regulations because the local steel mill executives were viewed as too strong to challenge. He notes that leadership in the mills did not have to actively repress or coerce residents to prevent their participation; reputational power and the belief that citizen engagement would have no influence sufficiently lessened their expectations and demands. 
This third dimension of power contributes to the shape and content of the political agenda by preventing issues, especially those that challenge the status quo, from even entering public consciousness or debate. It also suggests that social workers should be trained in methods supporting the development of political alternatives and critical consciousness among the public. When social workers fail to engage in such efforts, perhaps because they do not consider them to be within their purview, they may inadvertently render the profession to the "margins of political discourse" (Reisch, 2000, p. 293).

\section{Multiple dimensions of power in the U.S. federal system}

Presently, many social work policy courses focus on policies that are already in place. When such courses also include political advocacy theory or skills that showcase tactics such as voting, petitions, and letter writing, they may aim to influence issues that are on the political agenda. Although these tactics can support the passage or rejection of legislation, they need to be complemented with engagement that takes place earlier in the policy-making process at the stage when issues are framed and political agendas are set. Without an understanding of the second and third dimensions of power, social workers will inadvertently curtail their ability to influence policy.

To address this gap in content, we consider two prominent features of contemporary American politics — party polarization and racial bias — to demonstrate how the second and third dimensions of power influence political outcomes. From there, we conclude by providing content and exercises that can be incorporated into social work policy courses.

\section{Agenda control in a politically polarized environment}

The traditional pluralistic approach to understanding legislative governance assumes that policy proposals compete in an open marketplace of ideas, where all issues have an equal chance to come up for deliberation. However, there is little empirical evidence that traditional pluralism appropriately describes policy making in the U.S. political system, in part because of the ability to keep issues out of contention through agenda control (Zubek, 2011).

Cox and McCubbins (2005) have described how and why agenda control is employed in the U.S. Congress. Their work proceeded from the following set of assumptions. First, the political party that controls the majority of members is motivated to remain in power. Because political parties are, to the electorate, essentially a brand name, party leadership aims to project the image that the party is an effective presence in government. Second, the leaders of political parties do not want issues that have the potential to divide their party members in the legislative chamber to enter the political discourse. Leaders aim to advance issues that the majority of their members (most Democrats or most Republicans) are in agreement on, and they aim to suppress issues that elicit 
a lack of unity among members. Issues that split the party could damage that party's reputation or brand; a bill passed by the minority party with the support of a portion of the majority party would make the majority appear divided and ineffectual. Third, party leaders can use legislative procedures to ensure that bills that are controversial in their own party do not make it onto the legislative agenda (i.e., do not come up for a vote), which is a process known in political science as negative agenda control. For example, committee chairs in legislatures are members of the majority party and have a great deal of control over which bills are sent to the entire chamber for a vote. The party can use these powers to manage the issues that will even be considered by the full legislature.

Examining roll call votes, Cox and McCubbins (2005) found evidence for this type of process: very few bills pass the House of Representatives with the support of less than a majority of the majority party. If the House is under Democratic control, for instance, it is unlikely that a bill would even be considered if it appears it would pass with a majority of Republicans and a minority of Democrats. Additionally, although much of the scholarship on agenda control focuses on the House of Representatives, similar evidence has been found in the Senate (Gailmard \& Jenkins, 2007). The work of Cox and McCubbins (2005) suggests it is important to conceive of the legislative agenda in terms beyond the issues that are voted on or implemented.

The power of agenda setting is even more important when political parties are ideologically polarized. On average, the Democratic and Republican parties have been moving away from one another since the late 1970s (McCarty, Poole, \& Rosenthal, 2006). This trend holds true at the state and federal levels (Shor \& McCarty, 2011). As a result, many bills that are favored by one party are likely to be opposed by the other (Layman, Carsey, \& Horowitz, 2006; McCarty, Poole, $\&$ Rosenthal, 2009). This ideological divide, combined with an aversion to taking up issues that might split the majority party's members, creates a very narrow set of issues that will make it onto the legislative agenda. Furthermore, the range of issues will shift depending on which party controls the majority. Consequently, by training social workers to understand the rules of the game, including mechanisms of agenda control, they will be better equipped to strategically navigate political systems.

\section{Shaping political preferences and ideologies}

The mechanism of the third dimension of power is the least visible of the three because it relates to the power of ideas rather than to explicit action, as in the formal policy-making process. The third dimension of power, which involves values, beliefs, attitudes, and social norms, defines what the social problem is and suggests whether it is possible, necessary, or even desirable to change the status quo (Gaventa, 1980; Lukes, 2005). Hence, some political issues are understood as viable, whereas others are dismissed or not even imagined. It is particularly important for social workers to be trained in identifying and using this dimension of power, which not only can 
limit and control political agendas that threaten the status quo but can also be used to deliver policy and social change by reframing underconsidered issues as viable.

Although this dimension of power can be understood through the examination of assumptions relating to any social phenomenon (including classism, sexism, and heterosexism), race continues to be one of the most prevalent influences for how issues are framed and interpreted in U.S. politics. Social workers risk ignoring their own biases and could unnecessarily limit their engagement with the advancement of social and racial justice if they fail to understand the significance of race. Thus, to bring this theory to life, we suggest that social work educators draw from the rich body of research on how racial attitudes strongly influence beliefs about candidates, issues, and even perceptions of the role of government.

There is a growing body of research on how race and ethnicity, beyond the White-Black paradigm, shape political outcomes (DeLaGarza, 2004; Lee, 2000; Oliver \& Wong, 2003; Wilkinson, 2014). For the purposes of this article, however, we limit our focus to foundational studies on Black-White racial attitudes and public opinion because they lay the basis for, and open the dialogue to, more recent research on other populations, such as Asian Pacific Islanders, Latinxs, Middle Easterners, and North Africans. Here, we review research that links the racial attitudes of Whites and Blacks to the development of their political preferences and public opinion (Sears \& Kinder, 1971).

At the most basic level, voters who are Black and White have been found to prefer candidates of their own race, and the electoral success of Black candidates is often limited to political jurisdictions with a majority of Black voters (Barker, Jones, \& Katherine, 1999; Menifield \& Endersby, 2000; Walton \& Smith, 2015). Racial differences also map onto policy preferences: Blacks and Whites significantly differ in their support for policies that explicitly aim to reduce racial inequality (e.g., affirmative action or employment protections) and these differences in public opinion remain when evaluating policies that are not explicitly oriented toward race (e.g., general government spending on social services, health care, education, and assistance for the poor) (Kinder \& Winter, 2001; Schuman, Steeh, Bobo, \& Krysan, 1997).

Additionally, research suggests that public opinion can be manipulated depending on how issues are framed in the media. For instance, experiments have shown that assessments of policies that are not race based, such as health care, can be polarized along racial lines when the policy is associated with President Barack Obama compared to President Bill Clinton (Tesler, 2012). Similarly, experiments have shown that when the media emphasizes the cost of immigration associated with Latinx immigrants compared with European immigrants, White opposition increases (Brader, Valentino, \& Suhay, 2008). Thus, by including racial cues that aim to activate 
unconscious associations with race, the process of racial priming has significant effects on public opinion and policy preferences (Tesler, 2014; Valentino, Hutchings, \& White, 2002).

There are three competing explanations for why Whites oppose policies that either explicitly or indirectly challenge racial inequalities. All of them attempt to explain the underlying beliefs that shape this opposition. The first theory suggests that although overt racism has declined, symbolic racism has emerged in its place (Kinder \& Sears, 1981; Sears, 1988; Sears \& McConahay, 1973). Symbolic racism is a belief system that suggests that Blacks no longer face structural barriers and that any failure among Blacks (or others) is because of the individual's lack of hard work, Blacks demand too much from the government and society, and Blacks have received more than they deserve from such sources (Henry \& Sears, 2002). Research supporting this theory suggests that symbolic racism and racial resentment strongly predict Whites' opposition to policies that enhance equal opportunity and outcomes for minorities (Rabinowitz, Sears, Sidanius, \& Krosnick, 2009). Furthermore, Whites with anti-Black attitudes are more likely to oppose social policies benefiting Blacks than social policies benefiting other groups, such as women (Rabinowitz et al., 2009).

Another theory suggests that White Americans oppose race-based social policies because of the belief that the redistributive nature of the policies violates the principal core American values of individualism, freedom, and fairness, not because Whites are opposed to racial equality (Sniderman \& Carmines, 1997; Sniderman \& Piazza, 1993). However, research has consistently demonstrated that symbolic racism and racial resentment toward Blacks tap into an attitudinal dimension separate from (and more powerful than) conservatism, individualism, or antiegalitarianism (Tarman \& Sears, 2005).

Finally, a third theory suggests that White Americans oppose race-based policies because of the perception that Blacks' rising up the social ladder represents a threat to Whites (Bobo, 2000; Bobo \& Hutchings, 1996). An assumption embedded in this theory is that individuals align themselves with the group they belong to (in this case, their racial group) and then competition emerges over resources such as jobs or prestige, which creates conflict.

Persistent social forces, such as symbolic racism, adherence to traditional American values and norms, and group competition and conflict, shape policy preferences that serve to maintain the existing social hierarchy, which is heavily based on racial inequality. Social workers who aim to fight successfully against policies that marginalize people of color (and other disempowered groups, such as immigrants, refugees, and those living in poverty) need to understand the ways that issue framing can be used to construct and manipulate the legislative agenda.

\section{Incorporating the three dimensions of power in social work policy education}


If social work education is to prepare practitioners for successful advocacy in today's political climate, we must move beyond current discussions of power that focus solely on its first dimension. Understanding pluralism and the fundamentals of civics is critical, but by incorporating a multidimensional conceptualization of power into social work policy classes, educators will provide a comprehensive understanding of political processes and the skills needed to engage in them.

It may be helpful for some current instructors of social policy to note that Lukes's (2005) multidimensional framework of power complements the classical multiple-streams model of agenda setting and policy change by Kingdon (1984, 1993). In his model, Kingdon suggests that policies come to fruition when a policy window opens because of the convergence of three independent streams: (a) the problem stream, where a social condition is defined and recognized as a problem; (b) the political stream, where an issue rises to the policy-making agenda; and (c) the policy stream, where alternative policies are proposed, assessed, accepted, and made available. Although Kingdon's model provides insight into what enables policy change, it is not an easy task to recognize when these three streams come together or to actively influence the convergence of all three streams to open a policy window. Kingdon (1993) tends to downplay efforts to create policy windows, suggesting that change agents should "wait" for the policy windows to open and be ready to "seize" the opportunities when the time comes (p. 45). Lukes's analytical framework, on the other hand, is more approachable for individual social workers and applicable to various levels of advocacy because it helps social workers identify and develop the skills necessary to influence the three streams.

As an initial guide to incorporating Lukes's (2005) framework of power, we offer the following examples to help BSW- and MSW-level educators weave the second and third dimensions of power into social work policy curricula. Table 1 provides a list of suggested assignments and related resources. 
Table 1. Assignments and resources for teaching a multidimensional conceptualization of power.

\begin{tabular}{|l|l|l|l|}
\hline & Assignment & Description & Resources \\
\hline $\begin{array}{l}\text { Second } \\
\text { dimension of } \\
\text { power: agenda } \\
\text { setting }\end{array}$ & $\begin{array}{l}\text { Issue } \\
\text { framing in } \\
\text { media }\end{array}$ & $\begin{array}{l}\text { Students select an issue of interest } \\
\text { and search for mention of it in } \\
\text { mainstream and political } \\
\text { media }\end{array}$ & $\begin{array}{l}\text { Major news outlets (New York } \\
\text { Times, Washington Post, CNN, etc.), } \\
\text { The Hill (https://www.thehill.com), } \\
\text { Roll Call (https://www.rollcall.com) }\end{array}$ \\
\cline { 2 - 4 } & $\begin{array}{l}\text { Legislative } \\
\text { agenda, bill } \\
\text { tracking }\end{array}$ & $\begin{array}{l}\text { Students search for legislation related } \\
\text { to their selected issue }\end{array}$ & $\begin{array}{l}\text { U.S. Congress } \\
\text { (https://www.congress.gov/), Rocha } \\
\text { (2007), state legislature websites }\end{array}$ \\
\hline $\begin{array}{l}\text { Third dimension } \\
\text { of power: } \\
\text { issue framing and } \\
\text { political attitudes }\end{array}$ & $\begin{array}{l}\text { Analyzing } \\
\text { issue } \\
\text { framing }\end{array}$ & $\begin{array}{l}\text { Students examine the depiction of an } \\
\text { issue of interest, distinguishing } \\
\text { between the issue itself and how it is } \\
\text { framed or constructed }\end{array}$ & $\begin{array}{l}\text { Coates (2014), Isenberg (2016), } \\
\text { Staller (2010) }\end{array}$ \\
\hline $\begin{array}{l}\text { Multidimensional } \\
\text { conceptualization } \\
\text { of power }\end{array}$ & $\begin{array}{l}\text { Committee } \\
\text { hearing } \\
\text { simulation }\end{array}$ & $\begin{array}{l}\text { Students prepare for and participate } \\
\text { in a simulated committee hearing on } \\
\text { an assigned bill }\end{array}$ & $\begin{array}{l}\text { Haynes and Mickelson (2010), Lens } \\
\text { (2005), Stoesz (1993) }\end{array}$ \\
\hline
\end{tabular}

Recognizing that topics such as agenda setting, party polarization, and racial attitudes may not have immediate appeal to social work students, we recommend drawing students into discussions of power by focusing on political issues they are likely to have either personal or professional experience with. Depending on the amount of course time available, that could mean providing one example that most or all students are likely to relate to or allowing students to select their own issues to explore independently or in small groups. In the current political climate, many social work students may be interested in threats to the social safety net and other issues related to poverty and socioeconomic inequality, access to mental health care, support for immigrants and refugees, or something as personally relevant to students as the cost of higher education or student loan debt. Any of these issues can be used to help students better understand the roles of agenda setting, party polarization, and issue framing in the policy-making process.

\section{Teaching the second dimension of power}

Whether students are working as a whole class, in small groups, or individually, a good first step toward grasping the importance of agenda setting is to have students look for examples of their chosen issue in the political media. Ask them to explore major news outlets as well as websites such as The Hill (https://thehill.com) and Roll Call (https://www.rollcall.com), which focus specifically on news related to the U.S. Congress. Ask them if they are able to find information related to their chosen issue. If so, ask them what does it say? If they cannot find any 
information, ask them why they think this issue does not seem to be on the agenda? Although the media agenda and the policy-making agenda may not align perfectly, each has the power to influence the other; for example, issues students find in the media (particularly political media) are likely to be on the policy-making agenda as well (Dearing \& Rogers, 1996; McCombs \& Shaw, 1972).

Once students have become comfortable with the idea of agenda setting, the instructor can begin to move them toward an examination of legislative agendas more specifically. One excellent source for this is the official website of the U.S. Congress (https://www.congress.gov/) or most state legislatures' official websites, which allow users to search current and previous legislative sessions for issues of interest. This kind of search will help students see what has been on the legislative agenda in recent years and get a sense for the scope of issues that actually move through the legislative process (See Rocha, 2007, for more detailed instructions on bill tracking.). In our highly polarized political climate, it is relatively easy to find examples of partisan agenda setting, particularly if educators encourage students to consider how the agenda has shifted from the previous administration to the present one. Using a site like Congress.gov, social work educators can teach students to recognize agenda-setting power as follows:

We suggest using a site like Congress.gov search bar, enter an issue of interest. This will bring up a list of legislative items related to that issue. Students can choose to search "Current Legislation," which will show only items introduced in the current session of Congress, or "All Legislation," which will allow them to select earlier sessions of Congress as well. This exercise is also helpful for comparing agendas under different party's control.

If students are not familiar with the legislative process, the educator can choose a piece of legislation and walk students through the steps for passage, from the introduction of a bill to committee consideration, floor consideration, passage by the House and Senate, and signing by the president. Examining an actual bill can help students understand the length of time it takes for a bill to become a law and the complexity of the process itself. (Simulating a committee hearing, described later, is another way to help students understand this process.)

Using Congress.gov's various search limitation options (bill type, status in the legislative process, policy area, etc.), students can critically examine the bills introduced on a given issue, noting which bills moved from introduction to committee hearings and beyond and which were introduced but never advanced. Ask students to examine the relationship between the bills that advance and the party affiliations of those who introduced and supported it.

\section{Teaching the third dimension of power}


Once students have a grasp of the concept of agenda-setting power, they can move toward a deeper understanding of the third dimension of power, which involves attitude formation and issue framing. As an example, poverty and welfare have long been racially framed by the media and policy makers (Gilens, 1999), making this frame a particularly useful one for teaching students about the continued relevance of racial attitudes in U.S. political processes. One helpful exercise is to present students with images or advertisements related to a social issue and ask them to identify what the underlying social issue is, how it is being constructed or framed in that context, and what the implications of that framing might be for how the issue is addressed (or not addressed) by policy makers (Staller, 2010). For example, one group of students might be given an image that depicts U.S. poverty as the fault of an individual (or a group of individuals) who refuses hard work, such as a photograph of a downtrodden individual panhandling near a fast-food restaurant that has a Now Hiring sign visible in the window. From this image, students could draw a link to antipoverty policies that incentivize low-wage work. They might also recognize this as a frame that promotes individual responsibility for poverty, a view that is often used to keep redistributive policies off the legislative agenda. A second group of students might be given a graph that compares the amount of money it would take to end poverty in the United States with the amount the nation currently spends on military defense. Unlike their classmates in the first group, students in this group could link their image to political arguments that focus on funding priorities and budget debates as potential solutions to poverty.

A longer term framing project could ask students to trace a social issue over time to see how it has been framed differently in various historical and political contexts and to analyze what factors have played a role in that framing. Depending on the issue, this could include discussions of racial attitudes or assumptions about individual responsibility and equal opportunity. Examples of this type of analysis include Isenberg's (2016) work, which challenges national myths regarding individualism by documenting the history of poor Whites in the United States, and Coates's (2014) article, which challenges assumptions of equal opportunity by examining racial bias in social welfare policies. In any case, lessons about framing should include an explicit discussion about how particular ways of framing an issue can lead to its addition to, or exclusion from, the policy-making agenda. Helping students to understand why issue framing matters and how it has an impact on setting political agendas enhances their long-term ability to think critically about and engage effectively in the political process.

\section{Teaching a multidimensional conceptualization of power}

Once students have a sense of how social issues are framed and agendas are set, it is useful to provide them with experience in the complexities of politics and policy making. One way to do this is by having students simulate a congressional committee hearing. This experiential activity introduces students to the intricacies of the policy-making process, including the ways that 
political actors (social work advocates and others) can use issue framing and agenda-setting strategies to persuade members of Congress to support or reject legislation.

Because students are rarely familiar with the important role that committees play in the legislative process, it is helpful to remind them that this relatively small group of representatives or senators (particularly those who belong to the majority party) has the power to advance or shut down discussion on a particular topic. If a committee rejects a bill, it does not go before the rest of Congress. Acknowledging the power held by this small group can also help students to understand why advocacy efforts must be timely and targeted; it does little good to write letters or make phone calls to noncommittee members about a bill they may never see and much more good to address those who have decision-making power at the time when that power is most manifested (i.e., during committee hearings).

Using an issue that class members explored during the agenda-setting portion of the course, the instructor can select an actual bill that has been introduced to Congress and provide students with copies of the bill's text, allowing them to familiarize themselves with the language and format of legislation. It is important to select a bill of appropriate length for the amount of time planned for this activity. If the entire simulation will be conducted in one class session, for example, the bill should be no more than five pages in length so that students can actually read it in its entirety.

A class can simulate a committee hearing in a single session or over multiple class periods. If less time is available, the instructor can assign students roles and provide them with preresearched information about the issue and the perspective of someone who has been in their assigned role. If there is more time, the instructor can ask students to research the issue on their own and develop arguments based on their assigned role. In either case, students should play various roles, including those of legislators who sit on the committee in question; advocates, researchers, or other experts who have been called to testify at a hearing; and interested constituents who attend hearing proceedings and contact committee members in attempts to influence their votes (see Haynes \& Mickelson, 2010, Chapter 6 for more information on committee testimony.). Legislators can be provided with (or asked to research) details about their own voting records, constituent interests, and openness to new information, allowing students to recognize that some legislators may be on the fence about the bill in question and therefore more open to hearing different perspectives, whereas other legislators may be strongly predisposed to vote one way or another regardless of the testimony given during the hearing. Students assigned roles to testify at the hearing, as well as those assigned to be constituents, will need information about their particular interest in the bill. Again, students can be charged with doing their own research on these topics or be provided with enough information to construct an argument from a particular perspective. 
As students construct arguments, and while they are simulating the committee hearing, the instructor should ask them to point out the ways different arguments serve to frame the issue in different ways. For example, if the bill selected seeks to restrict the benefits people receive from a social safety net (or welfare) program, such as the Supplemental Nutrition Assistance Program or Temporary Assistance for Needy Families, the bill's supporters may frame the program as a wasteful handout and its recipients as lazy, willfully uneducated individuals who would rather live off the system than work to support themselves. Those who frame the issue this way have historically used racial stereotypes and attitudes, as well as assumptions about individual responsibility and equal opportunity, in making their case (Gilens, 1999; Isenberg, 2016). Opponents of the bill, on the other hand, might frame the program as a means of equalizing the resources available to all Americans by providing much needed support for hardworking parents or as the fulfillment of society's obligation to protect and provide for its children. Similarly, supporters of a bill attempting to restrict immigration could frame the issue as a matter of national security, connecting all immigrants from majority Muslim nations with Islamic extremists and terrorism, whereas opponents of that bill might frame it as an issue of human rights and present evidence that immigrants actually contribute to the U.S. economy rather than steal jobs from American citizens. Those presenting testimony should be encouraged to consider which frames might work best to convince specific legislators (Haynes \& Mickelson, 2010).

If time and the structure of the course allow, this type of simulation might also include lessons on how to identify legislators' positions on specific issues, the most effective ways (and times) to communicate with legislators, and how to craft a persuasive message (Lens, 2005; Stoesz, 1993). Such lessons should take into account not only the power to move issues onto the agenda and through the legislative process but also the power to prevent issues from moving forward. When the political agenda is focused on restricting marginalized groups' access to needed services, social workers must learn to target their advocacy efforts toward blocking such legislation. Social workers with deeper knowledge of the legislative process and of the multiple dimensions of power that are manifested in this process will have the ability to participate in this type of advocacy successfully.

Finally, students should be encouraged to think beyond the legislative, or other explicitly political, arena as they learn to employ a multidimensional conceptualization of power in their advocacy practice. As mentioned earlier, agenda setting and issue framing are not only used by political actors but also by the media and the general public. Social workers can help set the public agenda, which in turn affects the political agenda (Dearing \& Rogers, 1996) by raising issues in local and national media sources as well as on social media. Recent protests and rallies across the United States and around the world are excellent examples of the ways people can come together to push issues onto or shift issues off the national agenda. The strategies and skills 
described here can also be used in other contexts, such as schools, organizations, and community task forces (see Johnson, 1994), and at the state or municipal levels of government.

\section{Conclusion}

Social workers are not simply affected by social policy; under some conditions, they can influence it (Haynes \& Mickelson, 2010). In this article, we argue that social work curricula and general efforts toward political participation engage with the political system primarily through the first dimension of power. As members of a profession, we train our students and support practitioners in efforts to increase voter turnout and to educate decision makers through public testimony, petitions, and letter writing prior to voting on an issue. We applaud these efforts.

However, we also demonstrate that power can be exerted in political processes long before a given set of issues or policies are considered for a legislative or electoral vote. A bill cannot pass, for example, if agenda-setting control prevents it from consideration. This hidden aspect of policy making is particularly important when considering legislative policy change in an era of extreme party polarization.

Similarly, political power can be exerted through attitude formation, sometimes in unconscious ways. Although social identities including class can shape how people interpret political issues, we focus on racial priming as an example of a powerful way Americans determine their support for or opposition to candidates and policies, including those that do not explicitly aim to address racial inequality. Ideological power of this sort is broad and influential because it shapes whether and how the electorate conceives of social problems and appropriate solutions.

Given the complexity of the three dimensions of political power, and particularly in a polarized political context hostile to the core values of our profession, we encourage social work educators to incorporate a multidimensional conceptualization of power into their policy curriculum. This multidimensional framework helps to reveal the breadth and complexity of political processes. With sharper analytical tools, social work practitioners will be better equipped to strategically and effectively mobilize resources to advance social justice. 


\section{References}

1. Abramovitz, M. (1998). Social work and social reform: An arena of struggle. Social Work, 43, 512-526. doi:10.1093/sw/43.6.512 [Crossref], [Web of Science ${ }^{\circledR}$ ], [Google Scholar]

2. Abramovitz, M., \& Sherraden, M. S. (2016). Case to cause: Back to the future. Journal of Social Work Education, 52(sup1), 89-98. [Taylor \& Francis Online], [Web of Science (R], [Google Scholar]

3. Axinn, J., \& Stern, M. J. (2012). Social welfare: A history of the American response to need (7th ed.). Boston, MA: Pearson. [Google Scholar]

4. Bachrach, P., \& Baratz, M. S. (1962). Two faces of power. American Political Science Review, 56, 947-952. doi:10.2307/1952796 [Crossref], [Web of Science ${ }^{\circledR}$ ], [Google Scholar]

5. Barker, L., Jones, M., \& Katherine, T. (1999). African Americans and the American political system. Boston, MA: Pearson. [Google Scholar]

6. Beimers, D. (2016). Legislative advocacy days: Building political self-efficacy in social work students. Journal of Policy Practice, 15, 269-288. doi:10.1080/15588742.2015.1081577 [Taylor \& Francis Online], [Web of Science ${ }^{\circledR}$ ], [Google Scholar]

7. Bobo, L. (2000). Race and beliefs about affirmative action: Assessing the effects of interests, group threat, ideology and racism. In D. O. Sears, J. Sidanius, \& L. Bobo (Eds.), Racialized politics: The debate about racism in America (pp. 137-164). Chicago, IL: University of Chicago Press. [Google Scholar]

8. Bobo, L., \& Hutchings, V. L. (1996). Perceptions of racial group competition: Extending Blumer's theory of group position to a multiracial social context. American Sociological Review, 61, 951-972. doi:10.2307/2096302 [Crossref], [Web of Science ${ }^{\circledR}$ ], [Google Scholar]

9. Brader, T., Valentino, N., \& Suhay, E. (2008). What triggers public opposition to immigration? Anxiety, group cues, and immigration threat. American Journal of Political Science, 52, 959-978. doi:10.1111/ajps.2008.52.issue-4 [Crossref], [Web of Science ${ }^{\circledR}$ ], [Google Scholar]

10. Coates, T. (2014, June). The case for reparations. The Atlantic, 313(5), 54-71. [Google Scholar]

11. Council on Social Work Education. (2015). Educational Policy and Accreditation Standards. Retrieved from https://www.cswe.org/Accreditation/Standards-and-Policies/2015-EPAS.aspx Cox, G., \& McCubbins, M. (2005). Setting the agenda: Responsible party government in the U.S. House of Representatives. New York, NY: Cambridge University Press. [Google Scholar] 
12. Cox, G. W, \& McCubbins, M. D. (2005). Setting the agenda: Responsible party government in the US House of Representatives. Cambridge University Press. [Crossref], [Google Scholar]

13. Crenson, M. A. (1971). The un-politics of air pollution: A study of non-decision making in the cities. Baltimore, MD: Johns Hopkins University Press. [Google Scholar]

14. Culley, M. R., \& Hughey, J. (2008). Power and public participation in a hazardous waste dispute: A community case study. American Journal of Community Psychology, 41, 99-114. doi:10.1007/s10464-007-9157-5 [Crossref], [PubMed], [Web of Science ®], [Google Scholar]

15. Dahl, R. A. (1958). A critique of the ruling elite model. American Political Science Review, 52, 463-469. doi:10.2307/1952327 [Crossref], [Web of Science ${ }^{\circledR}$ ], [Google Scholar]

16. Dahl, R. A. (1961). Who governs?: Democracy and power in an American city. New Haven, CT: Yale University Press. [Google Scholar]

17. Dearing, J. W., \& Rogers, E. M. (1996). Agenda-Setting. Thousand Oaks, CA: Sage. [Google Scholar]

18. DeLaGarza, R. O. (2004). Latino politics. Annual Review of Political Science, 7, 91-123. doi:10.1146/annurev.polisci.7.012003.104759 [Crossref], [Web of Science ${ }^{\circledR}$ ], [Google Scholar]

19. DeRigne, L., Rosenwald, M., \& Naranjo, F. A. (2014). Legislative advocacy and social work education: Models and new strategies. Journal of Policy Practice, 13, 316-327. doi:10.1080/15588742.2014.929071 [Taylor \& Francis Online], [Google Scholar]

20. Fisher, R. (1995). Political social work. Journal of Social Work Education, 31, 194-203. doi:10.1080/10437797.1995.10672257 [Taylor \& Francis Online], [Web of Science ${ }^{\circledR}$ ], [Google Scholar]

21. Freire, P. (1970). Pedagogy of the oppressed (New rev. 20th-Anniversary ed.). New York: Continuum. [Google Scholar]

22. Gailmard, S., \& Jenkins, J. (2007). Negative agenda control in the Senate and the House: Fingerprints of majority party power. Journal of Politics, 69, 689-700. doi:10.1111/j.1468-2508.2007.00568.x [Crossref], [Web of Science ®], [Google Scholar]

23. Gaventa, J. (1980). Power and powerlessness: Quiescence and rebellion in an Appalachian Valley. Champaign: University of Illinois Press. [Google Scholar]

24. Gilens, M. (1999). Why Americans hate welfare: Race, media, and the politics of antipoverty policy. Chicago, IL: University of Chicago Press. [Crossref], [Google Scholar]

25. Haynes, K. S., \& Mickelson, J. S. (2010). Affecting change: Social workers in the political area (7th ed.). Boston, MA: Allyn \& Bacon. [Google Scholar] 
26. Henry, P. J., \& Sears, D. O. (2002). The symbolic racism 2000 scale. Political Psychology, 23, 253-283. doi:10.1111/pops.2002.23.issue-2 [Crossref], [Web of Science (®), [Google Scholar]

27. Hylton, M. (2015). Civic engagement and civic literacy among social work students: Where do we stand? Journal of Policy Practice, 14, 292-307. doi:10.1080/15588742.2015.1004396 [Taylor \& Francis Online], [Web of Science ${ }^{\circledR}$ ], [Google Scholar]

28. Isenberg, N. (2016). White trash: The 400-year untold history of class in America. New York, NY: Viking. [Google Scholar]

29. Johnson, A. K. (1994). Teaching students the task force approach. Journal of Social Work Education, 30, 336-347. [Taylor \& Francis Online], [Web of Science ${ }^{\circledR}$ ], [Google Scholar]

30. Kilbane, T., Pryce, J., \& Hong, P. Y. P. (2013). Advocacy week: A model to prepare clinical social workers for lobby day. Journal of Social Work Education, 49, 173-179. doi:10.1080/10437797.2013.755420 [Taylor \& Francis Online], [Web of Science ${ }^{\circledR}$ ], [Google Scholar]

31. Kinder, D. R., \& Sears, D. O. (1981). Prejudice and politics: Symbolic racism versus racial threats to the good life. Journal of Personality and Social Psychology, 40, 414-431. doi:10.1037/0022-3514.40.3.414 [Crossref], [Web of Science ${ }^{\circledR}$ ], [Google Scholar]

32. Kinder, D. R., \& Winter, N. (2001). Exploring the racial divide: Blacks, Whites, and opinion on national policy. American Journal of Political Science, 45, 439-456. doi:10.2307/2669351 [Crossref], [Web of Science ${ }^{\circledR}$ ], [Google Scholar]

33. Kingdon, J. W. (1984). Agendas, alternatives and public policies. Boston, MA: Little, Brown. [Google Scholar]

34. Kingdon, J. W. (1993). How do issues get on public policy agendas? In W. J. Wilson (Ed.), Sociology and the public agenda (pp. 40-50). Newbury Park, CA: Sage. [Crossref], [Google Scholar]

35. Lane, S. R., \& Humphreys, N. A. (2011). Social workers in politics: A national survey of social work candidates and elected officials. Journal of Policy Practice, 10, 225-244. [Taylor \& Francis Online], [Google Scholar]

36. Layman, G., Carsey, T., \& Horowitz, J. (2006). Party polarization in American politics: Characteristics, causes, and consequences. Annual Review of Political Science, 9, 83-110. doi:10.1146/annurev.polisci.9.070204.105138 [Crossref], [Web of Science ${ }^{\circledR}$ ], [Google Scholar]

37. Lee, T. (2000). Racial attitudes and the color line(s) at the close of the twentieth century. In P. M. Ong (Ed.), The state of Asian Pacific America: Transforming race relations (pp. 457-478). Los Angeles, CA: LEAP Asian Pacific American Public Policy Institute. [Google Scholar] 
38. Lens, V. (2005). Advocacy and argumentation in the public arena: A guide for social workers. Social Work, 50, 231-238. [Crossref], [PubMed], [Web of Science ${ }^{\circledR}$ ], [Google Scholar]

39. Lukes, S. (2005). Power: A radical view (2nd ed.). London, UK: Macmillan. [Crossref], [Google Scholar]

40. Mary, N. L. (2001). Political activism of social work educators. Journal of Community Practice, 9(4), 1-20. [Taylor \& Francis Online], [Google Scholar]

41. McCabe, H., Hylton, M., Kooreman, H., Sarmiento, M., \& Day, A. (2017). Civic literacy and social work education: Results from a multi-site study. Journal of Policy Practice, 16(1), 81-94. doi:10.1080/15588742.2015.1137852 [Taylor \& Francis Online], [Web of Science ${ }^{\circledR}$ ], [Google Scholar]

42. McCarty, N., Poole, K., \& Rosenthal, H. (2006). Polarized America: The dance of ideology and unequal riches. Cambridge, MA: MIT Press. [Google Scholar]

43. McCarty, N., Poole, K., \& Rosenthal, H. (2009). Does gerrymandering cause polarization? American Journal of Political Science, 53, 666-680.

doi:10.1111/ajps.2009.53.issue-3 [Crossref], [Web of Science ${ }^{\circledR}$ ], [Google Scholar]

44. McCombs, M., \& Shaw, D. (1972). The agenda-setting function of mass media. Public Opinion Quarterly, 36, 176-187. doi:10.1086/267990 [Crossref], [Web of Science ${ }^{\circledR}$ ], [Google Scholar]

45. Menifield, C., \& Endersby, J. (2000). Representatives, ethnicity, and Congress: Black and Hispanic representatives and constituencies. In Y. Alex-Assensoh \& L. Hanks (Eds.), Black and multiracial politics in America (pp. 257-272). New York: New York University Press. [Google Scholar]

46. Mills, C. W. (1959). The sociological imagination. New York, NY: Oxford University Press. [Crossref], [Google Scholar]

47. National Association of Social Workers (2017). Code of ethics. Retrieved from https://www.socialworkers.org/About/Ethics/Code-of-Ethics [Google Scholar]

48. Oliver, J. E., \& Wong, J. (2003). Intergroup prejudice in multiethnic settings. American Journal of Political Science, 47, 567-582. doi:10.2307/3186119 [Crossref], [Web of Science ${ }^{\circledR}$ ], [Google Scholar]

49. Polsby, N. W. (1960). How to study community power: The pluralist alternative. Journal of Politics, 22, 474-484. doi:10.2307/2126892 [Crossref], [Web of Science ${ }^{\circledR}$ ], [Google Scholar]

50. Pritzker, S., \& Burwell, C. (2016). Promoting election-related policy practice among social work students. Journal of Social Work Education, 52, 434-447.

doi:10.1080/10437797.2016.1198294 [Taylor \& Francis Online], [Web of Science ${ }^{\circledR}$ ], [Google Scholar]

51. Rabinowitz, J. L., Sears, D. O., Sidanius, J., \& Krosnick, J. A. (2009). Why do White Americans oppose race-targeted policies? Clarifying the impact of symbolic racism. 
Political Psychology, 30, 805-828. doi:10.1111/j.1467-9221.2009.00726.x [Crossref], [PubMed], [Web of Science ${ }^{\circledR}$ ], [Google Scholar]

52. Rees, S. (1991). Achieving power: Practice and policy in social welfare. Crows Nest, New South Wales, Australia: Allen \& Unwin. [Google Scholar]

53. Reisch, M. (2000). Guest editorial: Social workers and politics in the new century. Social Work, 45, 293-297. [Crossref], [PubMed], [Web of Science ®], [Google Scholar]

54. Reisch, M., \& Garvin, C. D. (2016). Social work and social justice: Concepts, challenges, and strategies. Oxford, UK: Oxford University Press. [Google Scholar]

55. Ritter, J. A. (2007). Evaluating the political participation of licensed social workers in the new millennium. Journal of Policy Practice, 6, 61-78. doi:10.1300/J508v06n04_05 [Taylor \& Francis Online], [Google Scholar]

56. Rocha, C. J. (2007). Essentials of social work policy practice. Hoboken, NJ: Wiley. [Google Scholar]

57. Rome, S., \& Hoechstetter, S. (2010). Social work and civic engagement: The political participation of professional social workers. Journal of Sociology \& Social Welfare, 37 , 107-129. [Google Scholar]

58. Schattschneider, E. E. (1960). The semi-sovereign people: A realist's view of democracy in America. New York, NY: Holt, Rhinehart and Winston. [Google Scholar]

59. Schuman, H., Steeh, C., Bobo, L., \& Krysan, M. (1997). Racial attitudes in America: Trends and interpretations. Cambridge, MA: Harvard University Press. [Google Scholar]

60. Sears, D. O. (1988). Symbolic racism. In P. A. Katz \& D. A. Taylor (Eds.), Eliminating racism: Profiles in controversy (pp. 53-84). New York, NY: Plenum Press. [Crossref], [Google Scholar]

61. Sears, D. O., \& Kinder, D. R. (1971). Racial tensions and voting in Los Angeles. In W. Hirsch (Ed.), Los Angeles: Viability and prospects for metropolitan leadership (pp. 51-88). New York, NY: Praeger. [Google Scholar]

62. Sears, D. O., \& McConahay, J. B. (1973). The politics of violence: The new urban Blacks and the Watts riot. Boston, MA: Houghton-Mifflin. [Google Scholar]

63. Shor, B., \& McCarty, N. (2011). The ideological mapping of American legislatures. American Political Science Review, 105, 530-551. doi:10.1017/S0003055411000153 [Crossref], [Web of Science ${ }^{\circledR}$ ], [Google Scholar]

64. Sniderman, P. M., \& Carmines, E. G. (1997). Reaching beyond race. Cambridge, MA: Harvard University Press. [Google Scholar]

65. Sniderman, P. M., \& Piazza, T. (1993). The scar of race. Cambridge, MA: Harvard University Press. [Google Scholar]

66. Specht, H., \& Courtney, M. E. (1995). Unfaithful angels: How social work has abandoned its mission. New York, NY: Simon \& Schuster. [Google Scholar] 
67. Staller, K. (2010). Social problem construction and its impact on program and policy responses. In S. B. Kamerman, S. Phipps, \& A. Ben-Arieh (Eds.), From child welfare to child well-being (pp. 155-173). New York, NY: Springer. [Crossref], [Google Scholar]

68. Stoesz, D. (1993). Communicating with the public. Social Work, 38, 367-368. [Web of Science $\left.{ }^{\circledR}\right]$, [Google Scholar]

69. Tarman, C., \& Sears, D. (2005). The conceptualization and measurement of symbolic racism. Journal of Politics, 67, 731-761. doi:10.1111/j.1468-2508.2005.00337.x [Crossref], [Web of Science ${ }^{\circledR}$ ], [Google Scholar]

70. Tesler, M. (2012). The spillover of racialization into health care: How President Obama polarized public opinion by racial attitudes and race. American Journal of Political Science, 56, 690-704. [Crossref], [Web of Science ${ }^{\circledR}$ ], [Google Scholar]

71. Tesler, M. (2014). Priming predispositions and changing policy positions: An account of when mass opinion is primed or changed. American Journal of Political Science, 59, 806-824. doi:10.1111/ajps.12157 [Crossref], [Web of Science ${ }^{\circledR}$ ], [Google Scholar]

72. Tilly, C. (1991). Reasons for the continuing growth of part-time employment. Monthly Laboratory Reviews, 114, 10-18. [Web of Science ${ }^{\circledR}$ ], [Google Scholar]

73. Valentino, N., Hutchings, V., \& White, I. K. (2002). Cues that matter: How political ads prime racial attitudes during campaigns. American Political Science Review, 96, 75-90. doi:10.1017/S0003055402004240 [Crossref], [Web of Science ®], [Google Scholar]

74. Walton, H., \& Smith, R. (2015). American politics and the African American quest for universal freedom (7th ed.). New York, NY: Pearson. [Google Scholar]

75. Wilkinson, B. C. (2014). Perceptions of commonality and Latino-Black, Latino-White relations in a multiethnic United States. Political Research Quarterly, 67, 905-916. doi:10.1177/1065912914540217 [Crossref], [Web of Science ${ }^{\circledR}$ ], [Google Scholar]

76. Zubek, R. (2011). Negative agenda control and executive-legislative relations in east central Europe, 1997-2008. Journal of Legislative Studies, 17, 172-192. doi:10.1080/13572334.2011.574025 [Taylor \& Francis Online], [Google Scholar] 